\author{
Zbigniew Kopeć \\ Instytut Filologii Polskiej \\ Uniwersytet im. Adama Mickiewicza w Poznaniu \\ e-mail: kzbsz@amu.edu.pl \\ ORCID: 0000-0003-4351-1137
}

\title{
Historia historii syberyjskiego związku Anny Slepcowej i Wacława Sieroszewskiego
}

Wacław Sieroszewski, jeden z bohaterów Rodowodów niepokornych Bohdana Cywińskiego ${ }^{1}$, należy do grona najbardziej znanych polskich zesłańców. Zasłużył na to działalnością naukową, literacką, polityczną i społeczną. Zdecydowanie łatwiej jest odesłać do odpowiednich kompendiów niż próbować przedstawić tu jego wkład w naukę, literaturę czy rozwój wolnej Polski². Jego nazwisko jest często przywoływane w pracach dotyczących badań etnograficznych Syberii. Ważnym wątkiem z jego biografii, który ostatnio zainteresował literaturoznawców, jest historia pobytu pisarza na zesłaniu ogniskująca się wokół Anny Slepcowej i ich wspólnej córki - Marii. Ten związek jest interesujący sam w sobie i ważny również jako element polskiego zesłańczego doświadczenia, jednak w tej pracy przedmiotem uwagi będzie wyłącznie to, jak o nim pisali literaturoznawcy i biografowie.

\footnotetext{
1 B. Cywiński, Rodowody niepokornych, Warszawa 1971.

2 Wspomnieć tu trzeba choćby o pracach monograficznych: K. Czachowski, Wacław Sieroszewski. Życie i twórczość, Lwów 1938; H. M. Małgowska, Sieroszewski i Syberia, Toruń 1973; I. Sadowska, Wśród obcych i wśród swoich. Wacława Sieroszewskiego portret wielokrotny, red. G. Legutko, Kielce 2007; A. Kijak, Odkrywca innej Syberii i Dalekiego Wschodu. O prozie Wactawa Sieroszewskiego, Kraków 2010; Wacław Sieroszewski. Zesłaniec - etnograf - literat - polityk, red. A. Kuczyński, M. Marczyk, Wrocław 2011. Warto tu też wspomnieć o biografii pisarza: A. Sieroszewski, Wacława Sieroszewskiego żywot niespokojny. Z rękopisu wydał, opracował i uzupełnił Andrzej Z. Makowiecki, Warszawa 2015.
} 
Ida Sadowska zauważa, że te fragmenty biografii dotyczące pobytu Wacława Sieroszewskiego, które mówią o jego założonej na Syberii rodzinie „realizują poetykę daleko idącej powściągliwości. Albo milczą całkowicie na temat jakuckiej rodziny, albo wzmiankują o niej mimochodem «między wierszami», marginalizując wyraźnie tę informację i umieszczając ją przy okazji jakichś innych, ważniejszych [...] wydarzeń" 3 .

Łatwo tę opinię potwierdzić, co wypadnie uczynić zaraz, ale też łatwo zadać pytanie o powody opisywanej przez Sadowską sytuacji, których odkrycie jest interesujące i ważne. Przyjdzie na to czas nieco później. Tezę Sadowskiej potwierdza już praca Michała Janika. W fundamentalnej dla badania obecności Polaków na Syberii książce pt. Dzieje Polaków na Syberii z 1928 roku $^{4}$ Janik o związku Sieroszewskiego ze Slepcową nie wspomina. Podobnie postępuje wymieniony przez Sadowską Kazimierz Czachowski zarówno w poświęconym Sieroszewskiemu paragrafie swojej syntezy historycznoliterackiej - Obrazie współczesnej literatury polskiej z roku 19345, jak i w monografii o życiu i twórczości Wacława Sieroszewskiego z roku $1938^{6}$. W książce Hanny Małgowskiej z roku 1973 znajduje się natomiast kilka krótkich wzmianek dotyczących związku Sieroszewskiego ze Slepcową i ich wspólnej córce - Marii 7 .

Jako klasyczny przykład „poetyki daleko idącej powściągliwości” Ida Sadowska wskazuje artykuł Andrzeja Lama z ważnego dla historii literatury polskiej opracowanego zbiorowo kompendium - Obraz literatury polskiej XIX i XX wieku. Idąc śladem badaczki twórczości Sieroszewskiego, pozwolę sobie jego fragment zacytować. Pisze Lam:

Jesienią 1885 ukończył opowiadanie Skradziony chłopak. Korzystał z zapomogi rządowej, tym potrzebniejszej, że z końcem zimy 1886 przejął pod swoją opiekę córkę Marię, której matka właśnie zmarła. Pomoc finansowa od przebywającej we Francji siostry Anny, żony Ludwika Waryńskiego, napotykała biurokratyczne przeszkody, ale sam fakt nadejścia przesyłki z zagranicy ułatwił Sieroszewskiemu starania o przeniesienie do ułusu namskiego [...], gdzie klimat umożliwiał zajęcie się rolnictwem ${ }^{8}$.

3 I. Sadowska, Egzotyczne rodziny polskich zesłańców syberyjskich - przypadek Wacława Sieroszewskiego, w: I. Sadowska, Wśród obcych i wśród swoich, s. 151.

4 M. Janik, Dzieje Polaków na Syberji, Kraków 1928.

5 K. Czachowski, Obraz wspótczesnej literatury polskiej 1884-1933, t. 1, Naturalizm i neoromantyzm, Lwów 1934.

6 K. Czachowski, Wacław Sieroszewski. Życie i twórczość, Lwów 1938.

7 H.M. Małgowska, Sieroszewski i Syberia, Toruń 1973, s. 151. Sadowska wymienia również: "hasła osobowe (Literatura polska. Przewodnik encyklopedyczny, PSB czy Obraz literatury polskiej)" wspominana jest też tu „Przedmowa Andrzeja Lama zamieszczona w dwudziestotomowym, powojennym wydaniu dzieł pisarza". 
Trudno Sadowskiej nie przyznać racji. Lam przedstawia postać Jakutki całkowicie przedmiotowo, próbuje postać matki córki Sieroszewskiego - pozwoliłem sobie tu użyć tego peryfrastycznego określenia - zmarginalizować, odmawiając jej cech indywidualizujących, takich jak np. wiek czy przyczyna przedwczesnej śmierci. Być może w PRL-u przełomu lat sześćdziesiątych i siedemdziesiątych informacja, że mężem siostry Wacława Sieroszewskiego był działacz socjalistyczny Ludwik Waryński, albo była niezmiernie istotna i ważna, albo też stanowiła poręczną ciekawostkę z życia rodziny autora $\mathrm{Na}$ kresach lasów, która pozwalała zneutralizować kłopotliwy wątek z biografii polskiego zesłańca.

Ida Sadowska zauważa, że „Maria znika z oficjalnej wersji życia swojego ojca", a jej obecność zostaje przesunięta „w sferę plotki”, gdy Sieroszewski po powrocie z zesłania ożenił się ze Stefanią Mianowską, a "wybory polityczne na trwałe związały go z postacią Józefa Piłsudskiego i narodowym skrzydłem socjalistów polskich, kultywujących romantyczne tradycje irredenty $[\ldots]]^{\prime 9}$. Tę obserwację potwierdzają "plotkarskie" fragmenty Wyznań gorszycielki Ireny Krzywickiej dotyczące autora Na kresach lasów, w których Maria, córka Sieroszewskiego i Slepcowej, została „zamieniona” w chłopca. Krzywicka urodziła się w Jenisejsku, gdzie na zesłaniu przebywali jej rodzice. Wspominając o trudnościach i pułapkach, jakie czyhały na Polaków zesłańców, pisze: „Byli też i tacy, którzy żenili się z Jakutkami i całkowicie zespalali z tubylczą ludnością. To jednak było na ogół źle widziane przez innych zesłańców, jako zaparcie się siebie. Wacław Sieroszewski miał podobno taką żonę Jakutkę i nawet syna, ale nigdy się do tego nie przyznawał" 10 .

Jako pozytywny przykład pisania o związku polskiego pisarza z jakucką kobietą Sadowska przywołuje pracę wnuka pisarza i profesora hungarystyki, Andrzeja Sieroszewskiego z roku 2001. I jej fragment pozwolę sobie zacytować:

W zesłańczej społeczności Wierchojańska najważniejszą postacią był Polak, Jan Zaborowski, zesłany za udział $\mathrm{w}$ powstaniu styczniowym. $\mathrm{W}$ jego domu pod koniec 1880 r. Sieroszewski poznał siostrę jego żony, dwudziestoletnią Jakutkę

\footnotetext{
8 A. Lam, Wacław Sieroszewski, Obraz literatury polskiej XIX i XX wieku, seria czwarta: Literatura polska w okresie realizmu i naturalizmu, red. J. Kulczycka-Saloni, H. Markiewicz i Z. Żabicki, Warszawa 1971, t. 4, s. 435.

9 I. Sadowska, Egzotyczne rodziny polskich zesłańców syberyjskich - przypadek Wacława Sieroszewskiego, w: I. Sadowska, Wśród obcych i wśród swoich, s. 158.

10 I. Krzywicka, Wyznania gorszycielki, Warszawa 1995, s. 20.
} 
Arinę Czełba-Kysa [czyli Annę Slepcową - dop. Z.K. ${ }^{11}$ ], z którą wedle miejscowych zwyczajów ożenił się. Na przełomie wiosny i lata 1882 r. (według niektórych autorów jeszcze w 1881 r.) urodziła im się w Wierchojańsku córka, nazwana przez ojca Marią. Jej matka, którą Sieroszewski we wspomnieniach nazywał Anną lub Annuszką, była nie tylko pierwszą jego nauczycielką języka jakuckiego i pomocnicą w spisywaniu wiadomości o Jakucji i Jakutach, ale pomagała mu też w przygotowaniach do obu ucieczek - pierwszej w lecie $1881 \mathrm{r}$. i drugiej w połowie 1882 r., obu zresztą nieudanych [...]. W zimie z 1886 na 1887 r. nieoczekiwanie zmarła ${ }^{12}$.

Narracja Andrzeja Sieroszewskiego nie próbuje wymazać Anny z biografii pisarza ani umniejszyć jej roli w jego syberyjskim okresie życia. Przeciwnie, bardzo tę rolę wyolbrzymia! Biograf pisarza (a równocześnie jego wnuk), próbuje w ten sposób - tak sądzę - pokazać wybrankę Wacława Sieroszewskiego jako osobę wyjątkową i mającą większy wpływ na jego życie i działalność naukową na Syberii niż dotychczas pisano. Taka strategia wymaga kilku komentarzy. Po pierwsze, pisząc o związku Jana Zaborowskiego z Jakutką, Andrzej Sieroszewski sugeruje, że sytuacja, w której znalazł się Wacław, nie jest niczym dziwnym ani wyjątkowym. Po drugie, informacja, że towarzyszka Sieroszewskiego jest powinowatą najważniejszej postaci środowiska zesłańczego w Wierchojańsku - Jana Zaborowskiego - z całą pewnością ma ją nobilitować. Po trzecie $\mathrm{w}$ końcu, pisze Andrzej Sieroszewski o pomocy, jakiej Anna Slepcowa miała udzielać mężowi m.in. podczas podejmowanych przez niego i jego towarzyszy prób ucieczki.

Warto się temu przyjrzeć bliżej. Opinii, że najważniejszą postacią w zesłańczej społeczności Wierchojańska był Polak Jan Zaborowski (powtarzanej przez innych badaczy twórczości Sieroszewskiego), nie potwierdzają znane mi prace poświęcone Zaborowskiemu ${ }^{13} \mathrm{i}$ innym zesłańcom politycznym przebywającym $\mathrm{w}$ Wierchojańsku ${ }^{14}$. Omawiając dokumenty z jakuckich archi-

11 Zawiłości związane nazwiskiem Anny Slepcowej wyjaśnia Grażyna Legutko w pracy: „Wyrosłam na Rosjankę...". Historia Marii - jakuckiej córki Wacława Sieroszewskiego - w świetle jej listów od ojca i innych dokumentów, Wrocław 2019, s. 18-22.

12 A. Sieroszewski, Słowo i czyn. Życie i twórczość Wactawa Sieroszewskiego, w: Z kraju nad Leną. Związki polsko-jakuckie dawniej i dziś, red. A. Kuczyński, Wrocław 2001, s. 136-138.

13 P.I. Korâkin, Â.O. Zaborovskij v Âkutskoj ssylke, "Âkutskij arhiv" 2009, no. 1.

14 P.L. Kazarân, Verhoânskaâ rolitičeskaâ ssylka vo vtoroj polovine XIX - načale XX v. Dissertaciâ na soiskanie učënoj stepeni kandidata istoričeskih nauk, Akademiâ Nauk SSSR, Dal'nevostočnyj Naučnyj Centr, Institut Istorii, Arheologii i Ètnografii narodov dal'nego vostoka 1985. Na pravah rukopisi, Vladivostok. 
wów, Petr Korâkin podkreśla, że Zaborowski był niepiśmienny i biedny. Ratunku przed biedą szukał w związku z jakucką kobietą, Marią Slepcową oraz w rzemiośle - był szewcem. Warto dodać, że sam Wacław Sieroszewski w swoich Pamiętnikach pisze o Zaborowskim, jako o człowieku, którego „Wszyscy lubili za humor i dobroć"15, ale ani słowem nie wspomina o tym, by był on "najważniejszą postacią" w Wierchojańsku. Nawiasem mówiąc, nie byłoby to chyba łatwe, ponieważ zesłańczą społeczność tworzyli tam głównie Rosjanie o daleko innych poglądach politycznych niż Zaborowski. O skomplikowanej sytuacji towarzysko-społeczno-politycznej zesłańców bardzo sugestywnie pisał Stiepanow:

stosunki wewnątrz "komuny" wygnańców w Wierchojańsku były bardzo złożone. W oczach miejscowych wszyscy byli takimi samymi „przestępcami państwowymi", ale w istocie wygnańcy reprezentowali różne polityczne trendy. Sieroszewski wspomniał [w Pamiętnikach ${ }^{16}$ - dop. Z.K.] ponurego nieczajecowca, który umarł podczas uczty. Nie pamiętał jego nazwiska. A była to niezwykła osobowość - N. N. Chazow, członek podziemnej organizacji Neczajewa, jeden z „biesów” opisanych w powieści Fiodora Dostojewskiego. W tym samym czasie na wierchojańskiej zsyłce przebywali E.I. Borisov, człowiek o umiarkowanie liberalnych poglądach i lekarz Ja. M. Biełyj, zwolennik stopniowego i ostrożnego narodnictwa ${ }^{17}$.

Trudno byłoby przypuszczać, by w takiej społeczności jakąś znaczącą rolę mógł odgrywać niepiśmienny Polak skazany za udział w powstaniu styczniowym.

Uściślić trzeba też informację o pomocy, jakiej miała udzielać Anna Slepcowa Wacławowi Sieroszewskiemu podczas podejmowanych przez niego prób ucieczek. Według relacji pisarza (czyli prawdopodobnie jednej z niewielu, jakie istnieją), Anna udzielała ich nieświadomie. Dopiero powrót Sieroszewskiego i jego towarzyszy z pierwszej nieudanej ucieczki mógł ją skłonić do podejrzeń: „Anuszka bardzo się ucieszyła z mego powrotu, coś się domyślała, ale nie rozpytywała się o nic" - pisał ${ }^{18}$. Przygotowania do drugiej ucieczki, polegające na budowie łodzi, i spowodowaną tym nieobecność Wacław tłumaczył Annie tak, jak pozostałym mieszkańcom Wierchojańska

15 W. Sieroszewski, Pamiętniki, w: tegoż, Pamiętniki. Wspomnienia. Dzieła, t. 16, red. A. Lam, J. Skórnicki, Kraków 1959, s. 278.

16 Tamże, s. 299.

17 S.A. Stepanov, Âkutskie vospominaniâ Vaclava Seroševskogo, v: Seroševskij Vaclav Leopol'dovič, Âkutskie rasskazy, povesti i vospominaniâ, Âkutsk 1997, s. 571.

18 W. Sieroszewski, Pamiętniki, s. 310. 
- pracą na zlecenie Amerykanów nad budową obserwatorium astronomicznego ${ }^{19}$. Pisze: „Moja Anuszka nie domyślała się, co się szykuje, i że ją wkrótce opuszczę [...]" 20 .

Analizując sposoby przedstawiana związku autora Dwunastu lat w kraju Jakutów i Anny Slepcowej warto zwrócić uwagę na jeszcze jeden szczegół: Andrzej Sieroszewski pisze, że Wacław Sieroszewski ożenił się z Anną według „miejscowych zwyczajów” (nie wyjaśnia jednak, czy faktycznie były to jakieś obrzędy zaślubin, czy też jedynie np. wspólne zamieszkanie) ${ }^{21}$, ale podobnie jak Lam, stara się unikać słowa „żona”, nazywając Annę Slepcową „matką Marii”. Być może ma to wskazywać na niedoskonałość prawną czy też nieważność ożenku polskiego zesłańca politycznego z jakucką kobietą. Sam Wacław Sieroszewski gdy wspomina Annę Slepcową jako ponad osiemdziesięcioletni mężczyzna, używa słowa „żona” (pisze np. „W Wierchojańsku pozwolono mi się zatrzymać zaledwie kilka dni. Zobaczyłem się z żoną i odwiedziłem córkę”; "Powiedzieliśmy sobie z żoną, że ją zabiorę, skoro tylko warunki pozwolą na wspólne mieszkanie" 22). Jednak zarówno Andrzej Lam jako edytor Pamiętników pisarza, jak i Andrzej Sieroszewski jako jego wnuk i ich wnikliwy czytelnik nie zawsze to akceptują. Co ciekawe, zgodnie $z$ jego sugestiami postępują wówczas, gdy piszą o siostrze Wacława, Annie, nazywając ją żoną Ludwika Waryńskiego. Tymczasem charakter związku Sieroszewskiego i Slepcowej oraz Sieroszewskiej i Waryńskiego jest dokładnie taki sam ${ }^{23}$.

\footnotetext{
19 Tamże, s. 326.

20 Tamże, s. 323.
}

21 Stwierdzanie, że ślub Anny Slepcowej odbył się według „zwyczaju jakuckiego” czy, jak pisze wnuk pisarza, według „miejscowych zwyczajów” po raz pierwszy pojawia się bodaj we Wspomnieniach Ludwika Krzywickiego [zob. L. Krzywicki, w: Wspomnienia, t. 2. Warszawa 1958, s. 450]. O obyczajowości związanej z zawieraniem małżeństw przez Jakutów pisze sam Sieroszewski w pracy Dwanaście lat w kraju Jakutów, o zawieraniu małżeństw na Syberii pisze też Maria Czaplicka, Mój rok na Syberii, przeł. H. Kossak-Nowocień, Toruń 2013, s. 91-100. Aleksandra Kijak i Grażyna Legutko, opierając się na opowiadaniach Adama Szymańskiego, piszą o syberyjskim zwyczaju zawierania małżeństw „na wiarę”. Zob. A. Kijak, Odkrywca innej Syberii i Dalekiego Wschodu. O prozie Wacława Sieroszewskiego, s. 16, Legutko, "Wyrostam na Rosjankę...". Historia Marii - jakuckiej córki Wacława Sieroszewskiego - w świetle jej listów od ojca i innych dokumentów, s. 24. Zob. A. Szymański, Pan Jędrzej Krawczykowski, w: Szkice, ze słowem wstępnym A. Grzymały Siedleckiego, Lwów 1921, s. 27.

22 W. Sieroszewski, Pamiętniki, s. 429. W innym miejscu Pamiętników pisarz deklaruje, że po dotarciu do Ameryki ściągnie do siebie żonę i córkę [s. 335].

23 Pisze Anna Kwiatek: „Jednak zdarzały się - i to nierzadko - związki nieślubne. Najbardziej chyba znaną spośród takich par byli Ludwik Waryński i Anna Sieroszewska, którzy poznali się w Genewie w latach osiemdziesiątych XIX w. Niestety, nie mamy ich osobistych relacji, a pamiętnikarze, którzy o tym wspominają, różnią się między sobą w wielu istotnych szczegó- 
Są przynajmniej dwie odpowiedzi na zadane na początku pytanie, dotyczące powodów milczenia o związku Slepcowej i Sieroszewskiego lub jego marginalizowania $\mathrm{w}$ pracach literaturoznawczych i biograficznych, stosowania „poetyki daleko idącej powściągliwości” lub - warto uzupełnić - strategii polegającej na wyolbrzymianiu roli Anny Slepcowej w życiu Wacława Sieroszewskiego.

Pierwsza odpowiedź związana jest ze sferą tabu ściśle reglamentującego to, co zesłańcom robić wolno, a czego im robić nie wolno. Opinię Ireny Krzywickiej dotyczącą etycznych zakazów, jakimi były objęte związki zesłańców z mieszkankami Syberii, powtarza Aleksandra Kijak, gdyż widzi ich odziaływanie również na obszar komunikacji. W powojennej rzeczywistości regulowały to, o czym wolno lub nie wolno mówić. Badaczka po analizie społecznej przestrzeni, w jakiej funkcjonował Sieroszewski, stwierdza: „przyjaźń z Józefem Piłsudskim, związek z narodowym odłamem polskich socjalistów, walka w Legionach w czasie I wojny światowej, reprezentowanie młodego państwa polskiego na międzynarodowych spotkaniach pisarzy, pełnienie funkcji publicznych, takich jak prezesura Polskiej Akademii Literatury i Polskiego oddziału Pen Clubu - te i wiele innych faktów sprawiły", że nie mógł on sobie pozwolić na ujawnienie posiadania "egzotycznej córki" ${ }^{24}$. Opinia współczesnej badaczki odsyła do historycznej sfery objętej tabu i znajduje swoje źródła zarówno we wspomnieniach zesłańców, np. Agatona Gilera, który deklarował:

odmawiamy szacunku publicznego tym rodakom, którzy się pożenili z Moskiewkami. Oni pomagają rządowi do wynarodowienia Polaków, niech się więc nie dziwią, że w sercu mamy dla nich pogardę. [...] Kilkunastu było takich, którzy boleść po stracie ojczyzny, słodzili pieszczotą na łonie żony obcego pochodzenia. Błądzili - a błądzić nie byli powinni, bo wiedzieli o swoich błędach ${ }^{25}$,

jak i w pracach z ostatnich lat przedstawiających wyniki badań nad zesłańczym etosem:

łach. Nie sposób zatem ze stuprocentową pewnością stwierdzić, czy w tym przypadku mamy do czynienia $\mathrm{z}$ «życiem na wiarę» jako realizacją socjalistycznego światopoglądu, na którą nie umieli się zdobyć Kelles-Krauzowie, czy też ze zbiegiem okoliczności uniemożliwiających legalizację, jak to sugerowali niektórzy autorzy wspomnień" [zob. A. Kwiatek, Nihiliści czy romantycy? Postawy polskich socjalistów wobec matżeństwa na przełomie XIX i XX w. (do 1914 r.) w świetle pamiętników, listów i literatury pięknej, „Przegląd Historyczny”, nr 101/2, 2010, s. 175-176].

24 A. Kijak, Odkrywca innej Syberii i Dalekiego Wschodu. O prozie Wactawa Sieroszewskiego, s. 16-17.

25 A. Giller. Opisanie zabajkalskiej krainy w Syberyi, Lipsk 1867, t. 1, s. 32. 
Wyjątkowo surowo piętnowane były przez społeczność wygnańczą związki małżeńskie Polaków z miejscowymi kobietami (Sybiraczkami), czemu dawano wyraz w wielu ustawach (statutach) zesłańczych i co stanowiło jedno z podstawowych założeń opracowywanych kodeksów moralnych ${ }^{26}$

- pisze Barbara Jędrychowska. „[...] «grzech» największy, jaki mógł popełnić polski zesłaniec polityczny - małżeństwo z miejscową kobietą, prawosławną" - stwierdza Jan Trynkowski ${ }^{27}$. Czesław Miłosz pisze, że to "moralno-polityczne tabu, równe niemal temu, jakie w stanie Mississippi strzeże białą kobietę od seksualnych stosunków z Murzynem" ${ }^{28}$. Trudną towarzysko sytuację takiego "grzesznika" pokazuje Stanisław Brzozowski w Płomieniach ${ }^{29}$. Wspomnienie Krzywickiej dowodzi, że normy te obowiązywały jeszcze na początku XX wieku, choć Mariusz Chrostek zwraca uwagę na to, że $\mathrm{z}$ biegiem lat stawały się coraz mniej rygorystyczne ${ }^{30}$. Przywołane tu prace koncentrują się raczej na związkach Polaków z Rosjankami - Sybiraczkami, nie podejmując zupełnie problematyki relacji zesłańców z autochtonkami, zatem i z Jakutkami. Tymczasem Sergej Glebow, pisząc o związku Sieroszewskiego i Slepcowej, nazywa go „tymczasowym małżeństwem kolonialnym", twierdząc, że takie małżeństwa były powszechne również wśród rosyjskich rewolucjonistów ${ }^{31}$. Jego obserwacje potwierdzają, przynajmniej w odniesieniu do polskich zesłańców, nazwiska noszone przez „potomków Polaków, których większość przodków to Jakuci lub Buriaci", jak pisze Ewa Nowicka - socjolog i antropolog społeczny, wyjaśniając ten fakt następująco: "Zesłańcy często zawierali małżeństwa z kobietami spośród rdzennych narodów Syberii (z Jakutkami, Ewenkijkami czy Buriatkami) między innymi dlatego, że $\mathrm{w}$ rodzinach rosyjskich byli źle widziani jako przyszli zięciowie. Zesłaniec kojarzył się z przestępcą, a w każdym razie był politycznie niewygodny" 32 .

\footnotetext{
26 B. Jędrychowska, Polscy zestańcy na Syberii 1830-1883. Działalność pedagogiczna, oświatowa i kulturalna, Wrocław 2000, s. 116-117.

27 J. Trynkowski, Kodeks etyczny zesłańca w świetle pism Agatona Gillera, „Studia Łomżyńskie", 14, 2003, s. 27.

28 Cz. Miłosz, Człowiek wśród skorpionów, Warszawa 1982, s. 13.

29 S. Brzozowski, Płomienie. Z papierów po Michale Kaniowskim, Warszawa 1983.

30 M. Chrostek, Etos dziewiętnastowiecznych zesłańców, Wrocław 2008.

31 S. Glebov, Siberian Ruptures. Dilemmas of Ethnography in Imperial Situation, w: An Empire of Others: Creating Ethnographic Knowledge in Imperial Russia and the USSR, red. R. Cvetkovski Roland, A. Hofmeister, Budapest - New York 2014, s. 306.

32 E. Nowicka, przy współudziale I. Kabzińskiej i R. Wyszyńskiego, Polacy czy cudzoziemcy? Polacy za wschodniq granica, Kraków 2000, s. 217.
} 
W tym samym obszarze tabu źródła mają zabiegi hiperbolizujące postać Anny Slepcowej i rolę, jaką odgrywała w wierchojańskim okresie życia Wacława Sieroszewskiego. Jej niezwykłość i wyjątkowość mają tłumaczyć zainteresowanie, jakim obdarzył ją Sieroszewski. Nie trzeba - myślę - udowadniać, że strategia polegająca na wyolbrzymianiu przymiotów Anny Slepcowej jest tak samo dla niej krzywdząca jak strategia Andrzeja Lama, i w podobny sposób rozmazuje rzeczywistość.

Ludwik Krzywicki pisze, że Sieroszewski żyjąc już w Warszawie, nigdy o swojej córce nie mówił ${ }^{33}$. Nie mówił też o Annie Slepcowej. Ale to raczej powody, na które wskazuje Giller i badacze zesłańczego etosu sprawiły, że Sieroszewski nie chciał upubliczniać szczegółów swojej zesłańczej przeszłości. O jego uczuciach do Slepcowej na podstawie pozostawionego przez pisarza materiału biograficznego trudno cokolwiek powiedzieć. Grażyna Legutko, która dla Sieroszewskiego i jego twórczości zrobiła bardzo wiele, podejmując dyskusję z Aleksandrą Kijak dotyczącą tej sfery życia pisarza, przywołuje „pełne ciepła literackie wizerunki Jakutek, których pierwowzorem była Arina” (czyli Anna) i wskazuje na "portret Byczy w Skradzionym chtopaku, Keremens w Chajlachu czy Anki w Dnie nędzy" ${ }^{4}$. Teza że Slepcowa była pierwowzorem tych bohaterek, jest chyba trudna do udowodnienia, prowokuje też pytania o to, czy inne jakuckie bohaterki prozy Sieroszewskiego są na niej wzorowane (również te, których wizerunki nie tylko nie są „pełne ciepła", ale mają charakter w różnym stopniu negatywny).

Upierałbym się, że lektura literackich utworów, na których autobiograficzność wskazuje sam Sieroszewski lub badacze jego twórczości, nie mówi nic albo prawie nic o jego żonie. Bez wątpienia teksty te pokazują swojego bohatera jako zesłańca, który ma (lub miał) żonę i dziecko, ale w żaden sposób nie wskazują na to, że jego żona jest (lub była) Jakutką. Warto przyjrzeć się bliżej dla przykładu jednemu z opowiadań pisarza. W opowiadaniu $W$ matni mowa jest o tym, jak wiedziona uczuciem ciężko chora kobieta jedzie wraz z córeczką na Syberię, by spotkać się tam z mężem zesłańcem. Być może uważny czytelnik tego utworu zastanawia się, w jakim języku rozmawia dziewczynka z jakuckimi dziećmi, ale szybko się orientuje, że kobieta przybyła z Polski, albo przynajmniej z Europy (o czym świadczy choćby jej europejska garderoba). Podążanie żon za przebywającymi na Syberii mężami-skazańcami wpisuje się $\mathrm{w}$ związany z zesłaniami repertuar gestów, nie tylko polskich, ale również np. rosyjskich. O sile jego oddziaływa-

\footnotetext{
33 L. Krzywicki, Wspomnienia, t. 3, Warszawa 1959, s. 270.

34 G. Legutko, „Wyrostam na Rosjankę...”. Historia Marii - jakuckiej córki Wactawa Sieroszewskiego - w świetle jej listów od ojca i innych dokumentów, s. 26.
} 
nia wiele mówi choćby wspomnienie Elizy Orzeszkowej, która nie pojechała na Syberię po powstaniu styczniowym za zesłanym tam mężem (dlatego, że go nie kochała, jak twierdzi), a potem nie była $z$ tej decyzji zadowolona. Pisze w 1896 roku:

Wówczas nie rozumiałam dobrze tego co czynię; potem stało się to dla mnie wyrzutem sumienia, który trwa dotąd. Ten brak ofiarności dla człowieka, który cierpiał za sprawę najdroższą, poczytuję sobie za jeden z najważniejszych, popełnionych w życiu błędów etycznych ${ }^{35}$.

Podobną problematykę podejmie potem w Nocy czerwcowej Jarosław Iwaszkiewicz. Jurij Łotman, pisząc o powodach decyzji Marii Wołkońskiej o udaniu się wraz z mężem na Syberię - stwierdza:

„Zawiniła” tu literatura rosyjska stworzywszy wyobrażenie o kobiecym ekwiwalencie heroicznego zachowania obywatelskiego oraz normy moralne dekabrystów, które domagały się bezpośredniego przenoszenia do życia zachowań bohaterów literackich ${ }^{36}$.

$\mathrm{Z}$ całą pewnością nie tylko polski, ale i rosyjski czytelnik interesujący nas tu fragment opowiadania $W$ matni, będzie czytał właśnie według tego kodu kulturowego.

Druga odpowiedź na postawione na wstępie pytanie związana jest $\mathrm{z}$ dostępną (a raczej z niedostępną) dla badaczy wiedzą dotyczącą syberyjskiego okresu życia Wacława Sieroszewskiego.

Bardzo skrupulatnie i pieczołowicie pokazuje Grażyna Legutko starania pisarza zmierzające do sprowadzenia córki Marii do Polski, korespondencję, jaką z nią prowadził, i pomoc materialną, jakiej jej udzielał. Były to jednak działania rozgrywające się $\mathrm{w}$ sferze raczej prywatnej. $\mathrm{W}$ swoich utworach wspomnieniowych: Ciupasem na Syberię ${ }^{37}$ z roku 1926 oraz Za kregiem polarnym $^{38}$ z roku 1929 Sieroszewski nie wspominał ani o Annie Slepcowej, ani o ich wspólnej córce Marii. Dlatego nie jestem pewien, kto powinien być adresatem uwag Idy Sadowskiej dotyczących braku informacji o ,jakuckiej rodzinie" pisarza np. w przywołanych tu pracach Kazimierza Czachowskiego, który właśnie na tych utworach wspomnieniowych Sieroszew-

\footnotetext{
35 E. Orzeszkowa, Autobiografia w listach [List II z 27 VII 1896 roku], [b.m. 1910], s. 12.

36 J. Łotman, „Dekabrysta w życiu codziennym”, w: Semiotyka dziejów Rosji, wyb. i przeł. B. Żyłko, Łódź 1993, s. 284.

37 W. Sieroszewski, Ciupasem na Syberię, Warszawa 1926.

38 W. Sieroszewski, Za kregiem polarnym, Warszawa 1929.
} 
skiego się opierał ${ }^{39}$, oraz oszczędnych wzmianek o Annie i Marii w monografii Hanny Małgowskiej. W moim przekonaniu Małgowska wspomina Annę Slepcową na tyle szczegółowo, na ile pozwalają je pamiętniki Sieroszewskiego wydane w roku $1959^{40}$. Brak informacji w pracach Czachowskiego i powściągliwość $\mathrm{w}$ ich przekazywaniu czytelnikowi w opracowaniu Małgowskiej wynika z braku wiedzy, której do pewnego momentu (np. do momentu druku jego Pamiętników i Wspomnień, kiedy stała się dostępna dla wszystkich) prawdopodobnie jedynym „dysponentem” był Wacław Sieroszewski, a nie ze złej woli, czy jakichś ukrytych intencji. O złą wolę trudno byłoby posądzić np. Siergieja Glebowa, który pisze, że Sieroszewski „po wyjeździe z Rosji nigdy się już ze swoją córką nie zobaczył" 41. I tu przyczyna leży w braku publikacji, do których badacz miałby dostęp.

Zaryzykowałbym tezę, że z biegiem czasu związek polskiego zesłańca Sieroszewskiego ze Slepcową - jakucką kobietą, stawał się dla piszących o autorze $W$ matni coraz bardziej akceptowalny. Świadczyć może o tym zmiana sposobów jego prezentacji. Można ją również dostrzec w pisanych w różnych okresach pracach tych samych autorów. Andrzej Sieroszewski np. w roku 2001 nobilitował Slepcową, pisząc o jej powinowactwach z „najważniejszą postacią” zesłańczej społeczności Wierchojańska, Zaborowskim. W roku 2015 wspomina już tylko, że Zaborowski był w Wierchojańsku postacią „szczególną", co praktycznie nic nie znaczy albo znaczy bardzo wiele ${ }^{42}$.

W ostatniej publikacji Legutko wyeksponowany jest natomiast inny wątek związany z Anną. Slepcowa ukazana jest jako osoba, dzięki której Sieroszewski poznaje język i kulturę jakucką. Legutko opiera tę tezę na wspomnieniach Salomona Liona z roku 1925, pt. Revolucjoniery za polarnom krugom, której fragment badaczka podaje za Stiepanowem w następującym tłumaczeniu:

Była gorącą patriotką i chociaż doskonale wszystko rozumiała i nieźle mówiła z nami po rosyjsku, uparcie odmawiała Sieroszewskiemu używania języka rosyjskiego i odpowiadała mu tylko wtedy, kiedy mówił do niej po jakucku. W ten sposób nauczyła go w ciągu jednej zimy rozumieć $i$ komunikować się po jakucku i dała mu świetny klucz do poznania narodu jakuckiego, jego historii i bytu ${ }^{43}$.

\footnotetext{
39 K. Czachowski, Wacław Sieroszewski. Życie i twórczość, Lwów 1938.

40 H.M. Małgowska, Sieroszewski i Syberia, Torun 1973, s. 39.

41 S. Glebov, Siberian Ruptures. Dilemmas of Ethnography in Imperial Situation, s. 306.

42 A. Sieroszewski, Wactawa Sieroszewskiego żywot niespokojny. Z rękopisu wydał, opracował i uzupełnił A.Z. Makowiecki, Warszawa 2015, s. 63.

43 G. Legutko, „Wyrostam na Rosjankę...”. Historia Marii-jakuckiej córki Wacława Sieroszewskiego - w świetle jej listów od ojca i innych dokumentów, s. 25.
} 
Nie sposób się nie zgodzić z badaczką wychwalającą talenty nauczycielskie Slepcowej, skoro wystarczyła jedna zima, by jej uczeń zaczął mówić i rozumieć po jakucku. Komentarza w tej sprawie wymaga jednak co innego - nazwanie Slepcowej patriotką pozwala widzieć jej związek z Sieroszewskim jako związek dwojga patriotów, walczących z carską tyranią, co samo w sobie już rodzi patos. Tymczasem Lion patriotyzm Slepcowej bierze w cudzysłów, jakby nie był pewien, czy może tego słowa użyć, dodając, że chodzi o patriotyzm „plemienny” (pisze: „Она была большой, так сказать, патриоткой своего племени" - „оna była wielką, by tak rzec, patriotką swojego plemienia" [wyróż. - Z.K.]) ${ }^{44}$. Ten fragment wypowiedzi Liona nie pojawił się w przytoczonym wyżej tłumaczeniu. Użycie słowa "patriotyzm” w odniesieniu do jakuckiej kobiety zmarłej w 1886 roku wymaga refleksji.

Kyunney Takasaeva twierdzi, że wśród ludu Sacha „Pojęcie narodu rozumianego jako polityczna emanacja pewnej wspólnoty etnicznej nie pojawiło się wcześniej niż na przełomie XIX i XX w." Dlatego w obiegu społecznym stosunkowo późno pojawiła się idea narodu, a po niej dopiero świadoma identyfikacja narodowa rozumiana jako rzeczywistość społeczna ${ }^{45}$. Pierwsze dziesiątki lat XX wieku miały dla tych procesów duże znaczenie ${ }^{46}$. Lion, publikując swoje wspomnienia w roku 1925, mógł przeszłość idealizować, ale musiał wiedzieć, jak skomplikowane są problemy etniczne i narodowościowe społeczeństw, które po 1918 roku współtworzyły ZSRR i jak wielką polityczną wagę i uwagę do nich przykładano ${ }^{47}$.

Można zaryzykować stwierdzenie, że w podobny sposób, jak w polskim literaturoznawstwie, kształtuje się obecność Anny Slepcowej w rosyjskich pracach poświęconych Sieroszewskiemu. I tu początkowo (przynajmniej w znanych mi opracowaniach) związek Sieroszewskiego ze Slepcową był pomijany, choć czasem z różnych powodów domagałby się merytorycznego komentarza. Na przykład Lûdmila Rovnâkova, omawiając frag-

44 S. Lion, Revolucionery za polârnym krugom, Moskva 1925, s. 82, cyt. za: S.A. Stepanov, Âkutskie vospominaniâ Vaclava Seroševskogo, s. 570.

${ }^{45}$ K. Takasaeva, Jakuckie prace Wacława Sieroszewskiego i zmiany kulturowe narodu Sacha, Warszawa 2020, s. 59 .

46 Zob. H. Takakura, Indigenous Intellectuals and Suppressed Russian Anthropology Sakha Ethnography from the End of the Nineteenth Century to the 1930s, "Current Anthropology" 2006, nr 6.

47 Zob. F. Hirsch, The Soviet Union as a Work-in-Progress: Ethnographers and the Category Nationality in the 1926, 1937, and 1939 Censuses, "Slavic Review” 1997, nr 2. 
ment listu autora Na kresach lasów do jednego z wydawnictw z 1909 roku, w którym Sieroszewski prosi, by egzemplarze książek wysłać jego córce do Moskwy, nie uznała, że trzeba wyjaśniać czytelnikowi, co córka pisarza Maria robi w Moskwie i kto jest jej matką. Być może takie informacje były najzwyczajniej poza sferą zainteresowania autorki, która zajmowała się korespondencją Sieroszewskiego, a nie jego relacjami rodzinnymi ${ }^{48}$. W podobny sposób postępuje autor monografii pt. Russko-âkutskie literaturnye svâzi $v$ proze (konec XIX - načalo XX v.) z roku 2001 Igor' Emel'ânov, której rozdział poświęcony jest właśnie Sieroszewskiemu ${ }^{49}$. Pozostawmy bez komentarza fakt uznania Sieroszewskiego za pisarza rosyjskiego, który sam w sobie jest warty osobnego studium, skupmy się natomiast na tym, że monografista - uczony z jakuckiego uniwersytetu - zwraca uwagę na etnograficzny charakter prozy Sieroszewskiego, a rezygnuje $z$ komentowania możliwości, że osobą wprowadzającą pisarza w świat jakuckiej kultury mogła być właśnie Jakutka, Anna Slepcowa. Jest to o tyle ciekawe i zastanawiające, że w Jakucji Sieroszewski cieszy się ogromną sławą jako pisarz oraz jako badacz, dzięki któremu uczniowie jakuccy mogą dowiedzieć się „wiele nowego i interesującego o swojej ojczyźnie" - jak pisze Olga Il'ina ${ }^{50}$ i gdzie ukazują się liczne publikacje o jego jakuckich (i nie tylko) losach. Towarzyszy temu refleksja dotycząca tego, jak te losy można prezentować na lekcjach. Anna Slepcowa przedstawiana jest w nich bez jakichkolwiek dodatkowych zastrzeżeń i wyjaśnień właśnie jako żona pisarza: „Jeszcze w Wierchojańsku pisarz ożenił się z Jakutką Anną Slepcową. Ona szybko umarła, pozostawiając córkę Marię. Uderzające jest to, że ojciec i córka korespondowali jeszcze do 1933 roku" $^{\prime 2}$. Związek Sieroszewskiej i Slepcowej omawia Stiepanow w artykule zamykającym zbór jakuckich utworów Sieroszewskiego ${ }^{52}$.

48 L.I. Rovnâkova, Vaclav Seroševskij i ego russkie korrespondenty (po materialam neizdannoj perepiski), v: Slavânskie literaturnye svâzi, red. M.P. Alekseev, Leningrad 1968, s. 152.

49 I.S. Emel'ânov, Russko-âkutskie literaturnye svâzi v proze (konec XIX - načalo XX v.), Novosibirsk 2001.

50 O.M. Il'ina, Regional'nyj kontekst v prepodavanii disciplin gumanitarnogo cikla: opyt vneklassnoj raboty, „Modern Humanities Succes / Uspehi gumanitarnyh nauk” 2020, nr 10, s. 25.

51 Savčenko I.V., Želobcova S.F. (2018), Proekt razrabotki mul'timedijnoj literaturnoj èkskursii "Svetpolârnoj Zvezdy". O žizni v Âkutii i naučno-literaturnom nasledii pol'skogo ssyl'nogo ètnografa XIX veka Vaclava Seroševskogo, v: Šag v budusee: teoretičeskie i prikladnye issledovaniâ sovremennoj nauki. Materialy XV Molodëžnoj Meždunarodnoj Naučno-Praktičeskoj Konferencii Studentov, Aspirantov i Molodyh Uと̌̈nyh, 24-25 aprelâ 2018 goda, g. Sankt-Peterburg, http://otkritieinfo.ru/f/sb_shag15_0.pdf [dostęp 18.07.2021].

52 S.A. Stepanov, Âkutskie vospominaniâ Vaclava Seroševskogo, s. 570. 
Żadnych wątpliwości związanych z charakterem związku Sieroszewskiego i Slepcowej nie ma wspominana już Kyunney Takasaeva. Pisze o Wacławie Sieroszewskimi i innym zesłańcu, Edwardzie Piekarskim: „W życiu Sieroszewskiego i Piekarskiego wspólne było również to, że mieli żony Jakutki. Historycznie potwierdzony jest fakt «związku małżeńskiego» tych zesłańców politycznych z jakuckimi «inorodkami» (od inaczej urodzone) ${ }^{53 "}$. Można było mieć nadzieję, że w jej ważnej monografii pt. Jakuckie prace Wacława Sieroszewskiego i zmiany kulturowe narodu Sacha Annie Slepcowej poświęcone będzie więcej miejsca tym bardziej, że autorka podkreśla swoją przynależność do narodu Sacha oraz fakt prowadzenia badań w Polsce ${ }^{54}$.

Pozwalał żywić tę nadzieję również tytuł rozdziału tej monografii, który brzmi "Żywe słowniki" o losach jakuckich żon polskich zesłańców. Jego pierwszy człon mówi, z jak cennymi i ważnymi źródłami wiedzy mieli bezpośredni kontakt badacze, ale też budzi negatywne skojarzenia $\mathrm{z}$ takimi związkami wyrazowymi jak „żywy trup", „żywa pochodnia” czy „żywa spiżarnia”. Odsyłają one do osób, które niebawem umrą (albo są już martwe), spłoną, np. dokonując samospalenia lub zostaną zjedzone np. w kanibalistycznym akcie. Stosunek do „żywych słowników” tych, którzy z nich korzystają (w tym przypadku czerpiąc wiedzę i umiejętności) określić można jako pasożytniczy. Tymczasem badaczka wskazuje interesujące tropy i nie wychodzi poza to, co już wcześniej napisano o Annie Slepcowej. Sama widzi role „żon-«inorodek»” w tym, że zesłańcy „dzięki nim łatwiej dostosowywali się do środowiska jakuckiego, szybciej uczyli się języka Sacha i mogli zbierać materiały do swoich badań: „żony-«inorodki»”, prowadziły bowiem gospodarstwa zesłańców oraz dbały o ich byt i wyżywienie" ${ }^{25}$. Takasaeva w sposób klarowny przedstawiła sytuację, w której role jakuckiej kobiety i białego mężczyzny są ścisłe określone, zauważa jednak, że „W Jakucji dotychczas temat «jakuckich żon-inorodok» jest dość emocjonalnie dyskutowany w mediach i na portalach internetowych" ${ }^{56}$. Badaczka tych dyskusji nie referuje ani do nich nie odsyła, wskazując jedynie nazwisko jednego z ich inicjatorów - profesora historii uniwersytetu w Jakucku Pavla L. Kazarâna. Prawdopodobnie dyskusje, o których pisze Takasaeva, dotyczą wywiadu z roku 2013, w którym

\footnotetext{
53 K. Takasaeva, Jakuckie prace Wacława Sieroszewskiego i zmiany kulturowe narodu Sacha, s. 117.

54 „Pochodzę z Jakucji, należę do narodowości Sacha i wychowałam się w niezasymilowanej rodzinie jakuckiej, dlatego podchodzę do kultury jakuckiej jako do własnej. Uważam, że ma to wiele zalet, chociażby znajomość języka jakuckiego. Moje pochodzenie, a ściślej mówiąc - przynależność etniczna, sprawia, że dobrze orientuję się we współczesnych problemach Jakutów i sytuacji w Republice Sacha" - pisze Kyunney Takasaeva [tamże, s. 29].

55 Tamże, s. 117.

56 Tamże, s. 118.
} 
Kazarân stwierdził m.in., że w Jakucji opiekunkami puli genowej są wyłącznie kobiety ${ }^{57}$. Historyk myślał tu prawdopodobnie właśnie o takich przypadkach, jak żony Piekarskiego i Sieroszewskiego. Deputowany Alaeksandr Daniłow publicznie oświadczył, że za tę wypowiedź, która obraża „,nasze matki i babcie" 58 , pozwie historyka do sądu. Widać nie tylko w Polsce trudno jest rozmawiać o związkach zesłańców z Jakutkami, ale również w Jakucji, gdzie ten problem widziany jest od drugiej strony i budzi większe emocje.

W pracy Trubadurzy imperium Thomson pisze, że mieszkańcy Taszkientu, w którym rozgrywa się akcja Oddziału chorych na raka Aleksandra Sołżenicyna, są w zasadzie przezroczyści, w powieści liczą się tylko Rosjanie ${ }^{59}$. W gruncie rzeczy tzw. suchych faktów związanych z osobą Anny Slepcowej też jest bardzo mało: miała siostrę, związała się z Wacławem Sieroszewskim, urodziła córkę Marię, prowadziła gospodarstwo Sergiejowi Kowalikowi ${ }^{60}$ i umarła w bardzo młodym wieku na płuca. Parafrazując nieznacznie tylko słowa Hélène Cixous, powiedzieć by można, że w Annie Slepcowej ogniskuje się historia wszystkich jakuckich kobiet, ich dzieje osobiste, historia narodowa i ponadnarodowa ${ }^{61}$, a jej historia - "herstory” jest równie ważna, jak historia Sieroszewskiego. Tymczasem Anna Slepcowa jest taką samą kobietą jak wiele innych jakuckich kobiet. Paweł Rodak, pisząc o „biografiach tych, którzy biografii nie mają" ${ }^{2}$, odwołuje się do koncepcji mikrohistorii. Do mikrohistorii odwołuje się również Lûdmila Ivanova podejmująca próbę rekonstrukcji życia codziennego jakuckiej kobiety z końca lat dwudziestych. Punktem wyjścia są dla niej notatki z wyprawy z 1928 roku, której celem było m.in. badanie życia rodzinnego i pozycji kobiet $\mathrm{w}$ ułusach Tattinskim i Bajagantajskim - w tym ostatnim w latach 1886-1887 mieszkał Sieroszewski. Obraz, jaki wyłania się z pracy Ivanovej, mówi, jak niełatwo było tej codzienności sprostać. $\mathrm{W}$ tym miejscu za badaczką mogę przywołać jedy-

57 P.L. Kazarian, Kazarân o mifah, ob istine i âkutah. (Polnyj tekst interv'û opublikovan v gazete «Naše vremâ» № 3 ot 25 ânvarâ 2013 g.), https://yakutsk.bezformata.com/listnews/kazaryano-mifah-ob-istine-i-yakutah/9181967/ [dostęp 18.07.2021]. Zob. też I. Nikolaev, Â soglasen s ocenkoj, čto Kazarân - provokator, http://uhhan.ru/news/2013-02-14-7167 [dostęp 18.07.2021].

58 A. Žondorov, Deputat Aleksandr Danilov hočet privleč' istorika Pavla Kazarâna k ugolovnoj otvetstvennosti, „Novosti Âkutii”, 29 ânvarâ, https://news.ykt.ru/article/8260 [dostęp 18.07.2021].

59 E. Thomson, Trubadurzy imperium. Literatura rosyjska i kolonializm, przeł. A. Sierszulska, Kraków 2000.

60 W. Sieroszewski, Pamiętniki, s. 447.

61 Zob. H. Cixous, Śmiech Meduzy, przeł. A. Nasiłowska, „Teksty Drugie” 1993, nr 4/5/6, s. 154. Sparafrazowany fragment brzmi następująco: „W kobiecie ogniskuje się historia wszystkich kobiet, ich dzieje osobiste, historia narodowa i ponadnarodowa".

${ }^{62}$ P. Rodak, O biografiach tych, którzy nie maja biografii, w: Biografia historiografia dawniej i dziś. Biografia nowoczesna nowoczesność biografii, red. R. Kasperowicz, E. Wolicka, Lublin 2005. 
nie jego fragmenty. Kobieta, której życie jest rekonstruowane, żyła w ciasnej, brudniej jurcie, niedostosowanej do skrajnego północnego klimatu, w której czasem mieszkały dwie-trzy rodziny, składające się "z gołych dzieci, ślepych staruszków", przez którą codziennie przechodziły krowy, żyjące w połączonej z nią oborze. Ivanova podkreśla, że jeśli jurta miała czterdzieści metrów kwadratowych, to obora stanowiła $78 \%$ jej całkowitej powierzchni, a mieszkanie $-22 \%$. W takiej jurcie mieszkało osiem osób (dwie rodziny) i dwadzieścia sztuk bydła. Do licznych obowiązków kobiety należało m.in.: dojenie i wyprowadzanie krów do wodopoju i sprzątnie nieczystości pozostawianych przez nie $\mathrm{w}$ jurcie, opieka nad dziećmi, przygotowywanie posiłków, a w okresie letnim również praca w polu. Bardzo ciężka praca, świat społecznych kontaktów ograniczony do jurty oraz skrajnie niehigieniczne warunki życia skutkowały licznymi chorobami, np. gruźlicą, co łącznie z innymi problemami, również psychicznymi, i częstymi samobójstwami, było przyczyną wysokiej śmiertelności znajdujących się $\mathrm{w}$ wieku rozrodczym jakuckich kobiet ${ }^{63}$. Co ciekawe, los jakuckich kobiet przedstawiony przez Ivanową, jest $\mathrm{w}$ wielu miejscach, mimo oczywistych różnic, zbieżny z tym, co z perspektywy polskiej pisała o kobietach w 1908 roku Cecylia Walewska ${ }^{64}$.

Sieroszewski w swoich pamiętnikach zastanawia się, czy właściwie postąpił, zabierając córkę z jej naturalnego środowiska, w którym może byłaby szczęśliwsza ${ }^{65}$. Zadając sobie to pytanie, pisarz ma już świadomość okropieństw rewolucji, obu wojen i stalinowskiego totalitaryzmu, czego, żyjąc w Moskwie, doświadczać musiała jego córka. Ale zabierając ją z rodzimego środowiska, nie mógł wiedzieć, co ją czeka w świecie. Wiedział natomiast, jaki los spotkał jej matkę, zmarłą na gruźlicę typową jakucką kobietę. Był to los, który stać się mógł i jej udziałem.

Opowiadanie o Annie Slepcowej w poetyce "daleko idącej powściągliwości", pomniejszanie jej roli w życiu Wacława Sieroszewskiego, albo jej nadmierne powiększanie, wynika z różnie motywowanej wstrzemięźliwości Wacława Sieroszewskiego w mówieniu o swoim życiu osobistym oraz z ograniczeń, jakie nakładali na siebie niektórzy jego biografowie i badacze twórczości. Paradoks polega na tym, że mimo takiej sytuacji, Anna Slepcowa mogła zaistnieć jako ważna postać w historii literatury.

63 L.T. Ivanova, Istoriâ pousednevnosti: odin zimnij den' âkutskoj ženŝiny v 20-e gg. XX v., http:// dom-hors.ru/rus/files/arhiv zhurnala/fik/2015-6/history/ivanova.pdf [dostęp 18.07.2021].

64 C. Walewska, Z dziejów krzywdy kobiet, Warszawa 1908.

65 W. Sieroszewski, Pamiętniki, s. 429. 


\section{Bibliografia}

Brzozowski Stanisław (1983), Płomienie. Z papierów po Michale Kaniowskim, Warszawa: Iskry.

Chrostek Mariusz (2008), Etos dziewiętnastowiecznych zesłańców, Wrocław: Polskie Towarzystwo Ludoznawcze.

Cixous Hélène (1993), Śmiech Meduzy, przeł. A. Nasiłowska, „Teksty Drugie”, 4/5/6, s. $147-166$.

Cywiński Bohdan (1971), Rodowody niepokornych, Warszawa: Biblioteka „Więzi”.

Czachowski Kazimierz (1934), Obraz współczesnej literatury polskiej 1884-1933, t. 1. Naturalizm i neoromantyzm, Lwów: Państwowe Wydawnictwo Książek Szkolnych we Lwowie.

Czachowski Kazimierz (1938), Wacław Sieroszewski. Życie i twórczość, Lwów: Państwowe Wydawnictwo Książek Szkolnych we Lwowie.

Czaplicka Maria (2013), Mój rok na Syberii, red. naukowa i wprowadzenie G. Kubica, przeł. H. Kossak-Nowocień, Toruń: Muzeum im. Marii Znamierowskiej-Prüfferowej.

Giller Agaton (1867), Opisanie zabajkalskiej krainy w Syberyi, Lipsk: F.A. Brockhaus.

Glebov Sergey (2014), Siberian Ruptures. Dilemmas of Ethnography in Imperial Situation, w: An Empire of Others: Creating Ethnographic Knowledge in Imperial Russia and the USSR, red. R. Cvetkovski Roland, A. Hofmeister, Budapest - New York: Central European University Press, s. 281-310.

Hirsch Francine (1997), The Soviet Union as a Work-in-Progress: Ethnographers and the Category Nationality in the 1926, 1937, and 1939 Censuses, "Slavic Review", no. 2, s. 251-278.

Il'ina Olga M. (2020), Regional'nyj kontekst v prepodavanii disciplin gumanitarnogo cikla: opyt vneklassnoj raboty, "Modern Humanities Succes / Uspehi gumanitarnyh nauk", nr 10, s. 23-26.

Ivanova Lûdmila T. (2015), Istoriâ povsednevnosti: odin zimnij den' âkutskoj žensiny v 20-e gg. XX v., http://dom-hors.ru/rus/files/arhiv_zhurnala/fik/2015-6/history /ivanova.pdf [dostęp 18.07.2021].

Janik Michał (1928), Dzieje Polaków na Syberji, Kraków: Krakowska Spółka Wydawnicza.

Emel'ânov Igor' S. (2001), Russko-âkutskie literaturnye svâzi v proze (konec XIX - načalo $X X$ v.), Novosibirsk: Nauka.

Jędrychowska Barbara (2000), Polscy zesłańcy na Syberii 1830-1883. Działalność pedagogiczna, oświatowa i kulturalna, Wrocław: Wydawnictwo Uniwersytetu Wrocławskiego.

Kazarân Pavel L. (1985), Verhoânskaâ rolitičeskaâ ssylka vo vtoroj polovine XIX - načale XX v. Dissertaciâ na soiskanie učënoj stepeni kandidata istoričeskih nauk, Akademiâ Nauk SSSR, Dal'nevostočnyj Naučnyj Centr, Institut Istorii, Arheologii i Ètnografii narodov dal'nego vostoka. Na pravah rukopisi, Vladivostok. 
Kazarân Pavel L. (2015), Kazarân o mifah, ob istine i âkutah. (Polnyj tekst interv'û opublikovan v gazete «Naše vremâ» № 3 ot 25 ânvarâ 2013 g.), https://yakutsk. bezformata.com/listnews/kazaryan-o-mifah-ob-istine-i-yakutah/9181967/ [dostęp 18.07.2021].

Kijak Aleksandra (2010), Odkrywca innej Syberii i Dalekiego Wschodu. O prozie Wacława Sieroszewskiego, Kraków: Wydawnictwo Uniwersytetu Jagiellońskiego.

Korâkin Petr I. (2009), Â.O. Zaborovskij v Âkutskoj ssylke, "Âkutskij arhiv” , no. 1, s. 28-33.

Krzywicka Irena (1995), Wyznania gorszycielki, Warszawa: Czytelnik.

Krzywicki Ludwik (1958), Wspomnienia, t. 2, Warszawa: Czytelnik.

Krzywicki Ludwik (1959), Wspomnienia, t. 3, Warszawa: Czytelnik.

Kuczyński Antoni, Marczyk Mirosław [red.] (2011), Wacław Sieroszewski. Zesłaniec etnograf - literat - polityk, Wrocław: Wydawnictwo Katedry Etnologii i Antropologii Kulturowej Uniwersytetu Wrocławskiego.

Kwiatek Anna (2010), Nihiliści czy romantycy? Postawy polskich socjalistów wobec małżeństwa na przełomie XIX i XX w. (do 1914 r.) w świetle pamiętników, listów i literatury pięknej, "Przegląd Historyczny”, nr 2, s. 171-196.

Lam Andrzej (1971), Wacław Sieroszewski, w: Obraz literatury polskiej XIX i XX wieku, seria czwarta: Literatura polska w okresie realizmu i naturalizmu, t. 4, red. J. Kulczycka-Saloni, H. Markiewicz, Z. Żabicki, Warszawa: Państwowe Wydawnictwo Naukowe.

Legutko Grażyna (2019), „Wyrosłam na Rosjankę...”. Historia Marii - jakuckiej córki Wacława Sieroszewskiego - w świetle jej listów od ojca i innych dokumentów, Wrocław: Polskie Towarzystwo Ludoznawcze.

Lion Salomon (1925), Revolûcionery za polârnym krugom, Moskva: Novaâ Moskva.

Łotman Jurij M (1993), "Dekabrysta w życiu codziennym”, w: Semiotyka dziejów Rosji, wyb. i przeł. B. Żyłko, Łódź: Wydawnictwo Łódzkie, s. 254-320.

Małgowska Hanna M. (1973), Sieroszewski i Syberia, Toruń: UMK.

Miłosz Czesław (1982), Człowiek wśród skorpionów, Warszawa: Państwowy Instytut Wydawniczy.

Nikolaev Ivan (2013), Â soglasen s ocenkoj, čto Kazarân - provokator, http://uhhan.ru/ news/2013-02-14-7167 [dostęp 18.07.2021].

Nowicka Ewa (2000), Polacy czy cudzoziemcy? Polacy za wschodnia granica, Kraków: Zakład Wydawniczy Nomos.

Orzeszkowa Eliza (1910), Autobiografia w listach t. 3, [b.m.].

Rodak Paweł (2005), O biografiach tych, którzy nie maja biografii, w: Biografia historiografia dawniej i dziś. Biografia nowoczesna nowoczesność biografii, red. R. Kasperowicz, E. Wolicka, Lublin: Towarzystwo Naukowe Katolickiego Uniwersytetu Lubelskiego, s. 231-245.

Rovnâkova Lûdmila I. (1968), Vaclav Seroševskij i ego russkie korrespondenty (po materialam neizdannoj perepiski), v: Slavânskie literaturnye svâzi, red. M.P. Alekseev, Leningrad, s. 124-165. 
Sadowska Ida (2007), Wśród obcych i wśród swoich. Wacława Sieroszewskiego portret wielokrotny, red. G. Legutko, Kielce: Instytut Filologii Polskiej Akademii Świętokrzyskiej im. Jana Kochanowskiego.

Savčenko I.V., Želobcova S.F. (2018), Proekt razrabotki mul'timedijnoj literaturnoj èkskursii "Svetpolârnoj Zvezdy". O žizni v Âkutii i naučno-literaturnom nasledii pol'skogo ssyl'nogo ètnografa XIX veka Vaclava Seroševskogo, v: Šag v buduŝee: teoretičeskie i prikladnye issledovaniâ sovremennoj nauki. Materialy XV Molodëžnoj Meždunarodnoj Naučno-Praktičeskoj konferencii Studentov, Aspirantov i Molodyh Učënyh, 24-25 aprelâ 2018 goda, g. Sankt-Peterburg, s. 103-106, http://otkritieinfo.ru/f/sb_shag15_0.pdf [dostęp 18.07.2021].

Sieroszewski Andrzej (2001), Słowo i czyn. Życie i twórczość Wacława Sieroszewskiego, w: Z kraju nad Lena. Związki polsko-jakuckie dawniej i dziś, red. A. Kuczyński, Wrocław: Alta 2.

Sieroszewski Andrzej (2015), Wacława Sieroszewskiego żywot niespokojny. Z rękopisu wydał, opracował i uzupełnił A.Z. Makowiecki, Warszawa: Iskry.

Sieroszewski Wacław (1926), Ciupasem na Syberię, Warszawa: Rój.

Sieroszewski Wacław (1929), Za kręgiem polarnym, Warszawa: Rój.

Sieroszewski Wacław (1959), Pamiętniki. Z rękopisu wydał A. Lam, w: W. Sieroszewski, Pamiętniki. Wspomnienia. Dzieła, t. 16: Varia, red. A. Lam, J. Skórnicki, Kraków: Wydawnictwo Literackie, s. 7-520.

Sieroszewski Wacław (1961), Dwanaście lat w kraju Jakutów, w: W. Sieroszewski, Dzieła, t. 16, cz. 2: Varia, Kraków: Wydawnictwo Literackie.

Stepanov S.A. (1997), Âkutskie vospominaniâ Vaclava Seroševskogo, v: Seroševskij Vaclav Leopol'dovič, Âkutskie rasskazy, povesti i vospominaniâ, Âkutsk: Zdatel'skij dom Kuduk, s. 565-591.

Szymański Adam (1921), Pan Jędrzej Krawczykowski, w: A. Szymański, Szkice, Ze słowem wstępnym A. Grzymały-Siedleckiego, Lwów: Wydawnictwo Zakładu Narodowego imienia Ossolińskich, s. 15-30.

Takakura Hiroki (2006), Indigenous Intellectuals and Suppressed Russian Anthropology Sakha Ethnography from the End of the Nineteenth Century to the 1930s, "Current Anthropology", nr 6, s. 1009-1016.

Takasaeva Kyunney (2020), Jakuckie prace Wacława Sieroszewskiego i zmiany kulturowe narodu Sacha, Warszawa: Wydawnictwo DIG.

Thomson Ewa M. (2000), Trubadurzy imperium. Literatura rosyjska i kolonializm, przeł. A. Sierszulska, Kraków: Universitas.

Trynkowski Jan (2003), Kodeks etyczny zesłańca w świetle pism Agatona Gillera, „Studia Łomżyńskie", nr 14, s. 23-30.

Walewska Cecylia (1908), Z dziejów krzywdy kobiet, Warszawa: Gebethner i Wolff.

Žondorov Anton (2013), Deputat Aleksandr Danilovhočet privleč' istorika Pavla Kazarâna k ugolovnoj otvetstvennosti, „Novosti Âkutii”, 29 ânvarâ, https://news.ykt.ru/ article/8260 [dostęp 18.07.2021]. 


\title{
A Record of the History of the Siberian Relationship between Anna Sleptsova and Wacław Sieroszewski
}

\begin{abstract}
The paper discusses the means of presentation within the field of Polish studies of the relationship between Wacław Sieroszewski, a writer and ethnographer, one of the better known Polish exiles in Siberia, and a Yakut woman, Anna Sleptsova. The author contemplates why in the Polish studies their relationship has been omitted, marginalized or hyperbolized. This resulted from Sieroszewski's own reticence and the cultural taboo, which prohibited exiles from entering into relationships with Russian women. Additionally, the paper presents some Russian-language studies concerning Sieroszewski, in which Sleptsova, who was a significant writer and researcher for Yakutia, is openly referred to as Sieroszewski's wife.
\end{abstract}

Keywords: Siberia, Yakutia, exiles, taboo, women, Wacław Sieroszewski 